綜一說

色素體の細胞學的研究* II

湯 淺明

Akira YUASA: Cytological studies on plastids.* II

\title{
3. 色素體分裂について
}

コンテリクラマゴケの假根拒よび葉について觀察すると，三つの分裂の型がみられる。

1. ふつら型 (normal type) 從來知られているよ5K, 色素體が亞鈴形になつて二つにちぎれるるの であって, 1 細胞中火多数ふくまれている小葉綠體, 1 細胞中に 1 數個ふくまれている大形葉綠體的よび 有色體火みられるものであり，ての型の中にも二つの場合が區別される。一つは，亞鈴形火なつて分裂する ふつらのるのであり，他の一つはッッ゙ミモ型となつて分裂するるのである。

1 日の中，外界の狀態にしたがつて㾁とんぞつね分裂が行われているが，同化溊粉のみちているるの では, 分裂は少く, また, 分裂の途中で溉粉のでき始めたるのは一時, 分裂を中止し, ふたたび分裂を始め るときは，同化溉粉の量が少くなっているよらと思われる。

したがつて，分裂と同化澱粉の眝藏と連關があり，分裂が比較的依に多いといらととも，上述の事實と 關連しているょらである。したがつて，分裂を觀察するには，しばらく暗室中に入れて和いたものについて 行ら方がよい。

分裂の目際的觀察はつぎの二つの例の示すよ 5 K, 亞鈴形となるるのでは約 14 時間を要し, ッッ゙ミモ 型になるるのでは 9 時間以上を要した。圖 $6 \mathrm{c}$ g けふつ5型による分裂で, 畫間的よび夜間の分裂を連續 的にみて, 本均すると $\mathrm{c}$ の狀熊から d まで 2 時間, d e まで 7 時間, e〜g まで 5 時間で, 全過程には 約 14 時間を要する。6 圖 i〜p は虹波 12 號水溶液（濃度 10-7）を用いた場合で，ッッ゙ミモ型の分裂に約 5 時間を要してふふっらの場合より少し速くなっている。

分裂によつて二つになつた色素體は，ふたたび接合して融合するよらな感じを呈するととるあり。ま そ, 從來知られているよ5K，いくつもの色素體基質で連絡されて色素體連結を形成しているてとも多い。

1 細胞中の葉綠素の量はかなり一定しているょ5に思われ，色素體の大きいときは數は少く，小形のと きは數が多い。

2. 二割型（transverse type）1細胞中に 1 乃至数個の色素體がふくをれている場合の, 大形の色素體 と圭としてみられるるので, その他の場合にる觀察されるてとがある。すなおち 1 細胞中に 1 葉綠體をふく んでいて 2 葉綠體細胞に5つるるの（葉の基部細胞なぞ），2葉綠體細胞から多葉綠體細胞に5つるものな どとみらるる。

二割型の場合には葉綠體はすず中央部分にわれ目を生じ,一端からわれはじめ, 中央部の基質のみで連 絡した二つの杯狀となり，ついに二つに分離し，2葉緣體が完成する。1葉綠體が二割型によつて 2 葉綠體 となるときとは，核ははじめ葉綠體の表面にあり，しだいに葉綠體のわれ目に入りこむことがみられる。

* 東京大學敉養學部坐物學敉室業績 Contribution from the Biological Institute, Faculty of Culture, University of Tokyo. 

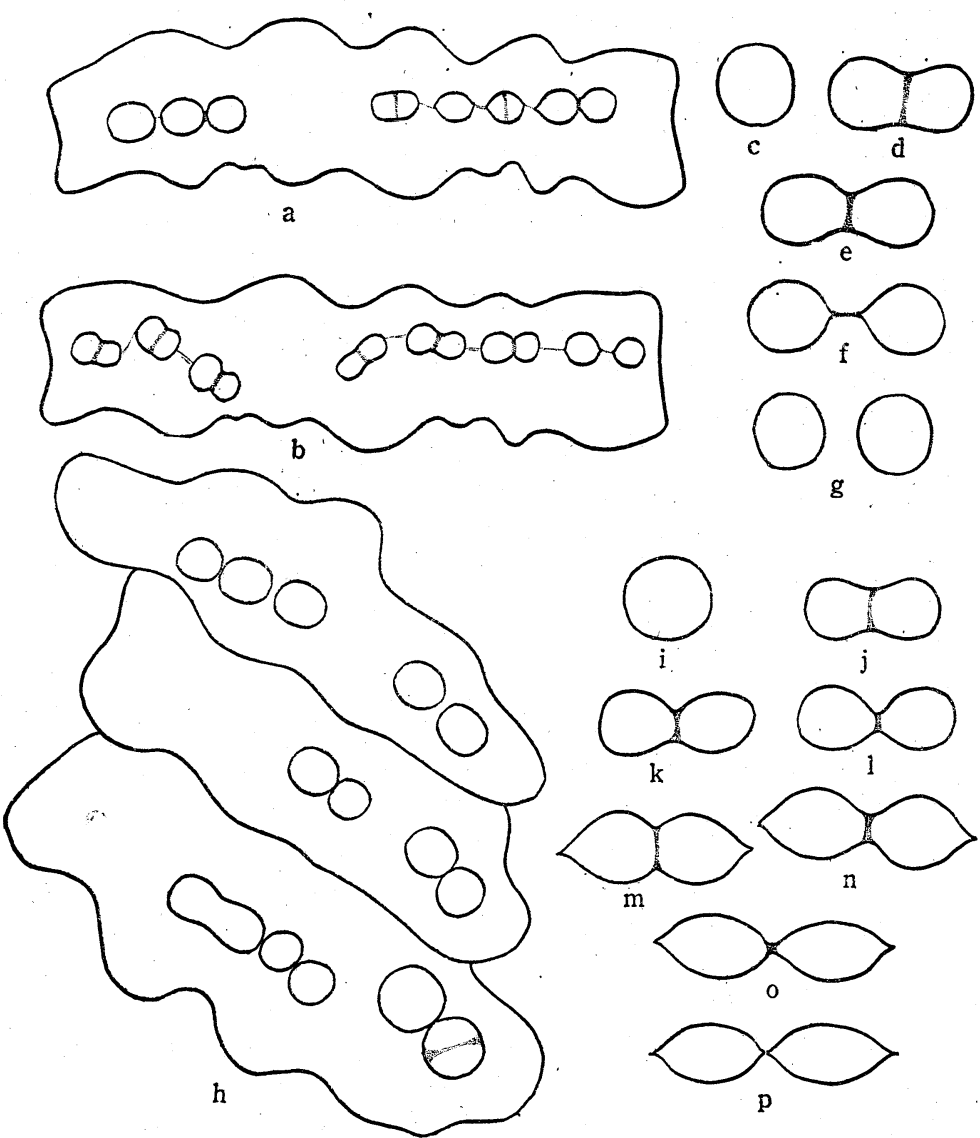

$g$
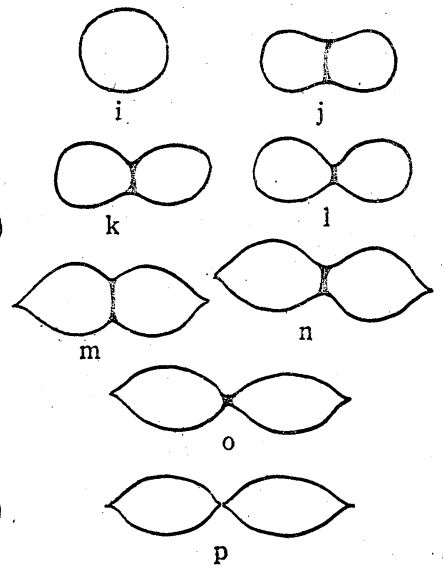

圖 6. コンテリクラマゴケの葉の裹面細胞中の葉綠體. a, 10 時の細胞狀態. b, 18 時火指ける同 じ細胞. c〜 g, ふつら型による葉綠體分裂. i〜 p, 葉の裹面細胞中のふつら型（ッッ゙ミモ型）による 分裂. h, 10 時 30 分の細胞狀態. この細胞の 1 葉綠體を追跡すると圖 $\mathrm{i} \sim \mathrm{p}$ のよ 5 と戀化した。 ただ L，虹波 12 號 $\left(10^{-7}\right)$. を媒體として觀察した。 i, 10 時 30 分. j, 10 時 50 分. k, 12 時. 1, 12 時 40 分. $\mathrm{m}, 14$ 時 20 分. $\mathrm{n}, 14$ 時 50 分. o, 15 時. p, 15 時 30 分. a, b, × ca. $700 . \mathrm{h}, \times \mathrm{ca} .750 . \mathrm{c} \sim$ g, $\times$ ca. 850 . i $\sim$ p, $\times$ ca. 85 J.

(原圖)

圖 7 は, 葉の莁部の 1 細胞中に 1 葉綠體のあるるのが 2 葉綠體となるときみられる二割型の分裂を追 跡したもので, 21 時 20 分から柆日の 9 時までに約 12 時間かかつた。

分裂中に分裂しつつある 2 部分の相互の位置はしばしば變化し，またをがいに和し合つたり，引合つ そりするよらするみられたが,てれは一部は原形質流動により，一部は分裂しつつある色素體の 2 部分間 の基質の流動によるものと考えられる。ときと分裂の逆もどりするととるある。

3. 縱割型 (longitudinal type). 有色體的よびきわめてわかい葉の細胞などにみられるるので, 色素 體は棒狀で，てれがわれて二つになるるのである。棒狀の色素體は上からみると圓形にみえることがある。

部分的に追跡した分裂過程をつぎ合せてみると，圖 8 のよらになり，まず棒狀の色素體は，その端部 にわれ目を生じて，しだいにわれ目を深めて二つの棒狀色素體となる。この綠ラセンはまわりながら 2 本 にとけるらしい。棒狀色素體はまた, しだいに太くなつて後, ふつら型によって分裂することるある。 
葉の基部の細胞中には色素體の數 が多く、また小形であり,葉の裹面和よ び葉柄の細胞內には小形色素體が多く 存在する。葉の表面扣よび內部細胞中 には 2 色素體をるち,きわめて若い葉で は, 細胞內には 2 色素體をたは 1 色素體 をるつか,あるいは分裂型がみられる。 これら種々な細胞間の移行は,つぎの よらと考えられる。

葉の基部の細胞中には葉綠體が多 數ふくまれて和りとこから落い葉が 形成されるために細盷が分裂すると， その細胞中には少數（1 個まをは 2 個） の葉綠體がふくまれるよらになり，葉 綠體は白色體の狀態に移行する。2個の 色素體をふくむるのは, 細胞の分裂に よって娘細胞住 1色素體をるち，ての色 素體は二分して 2 色素體の細胞となる。 また，2個以上の色素體を葉の基部細胞 からえたるのは，1または 2 色素體をの こして他は退化する。きわめて若い細 胞中で, 1〜2色素體をるつものの內部 飞退化色素體の小塊がみられる場合が あり,また, 退化色素體の內部が退化し て外部の膜のみのてつていて，色素體の外部に膜狀構造のあるととの證明となる場合るある。
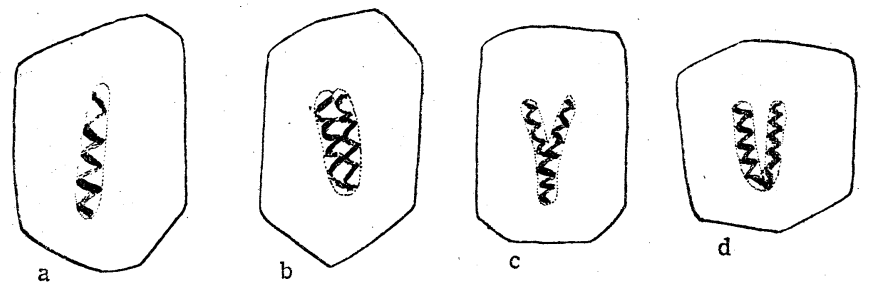

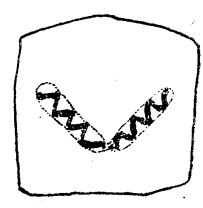

e

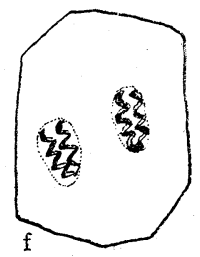

圖 7. $\mathrm{a}$ ｉ．二割型による分裂を，同一葉綠體にっいて追 跡したるの. × ca. 970. a, 21 時 20 分. b, 21 時 40 分. c, 23 時 20 分. d, 24 時 10 分. e, 2 時 30 分. f, 3 時. g, 4 時. h, 7 時 15 分. i, 9 時.

(原圖)

圖 8. a〜f, きわめて若い葉の細胞にみえる棒狀色素體の縱割型. $\quad \times$ ca. 870. a, 色素體中に 1 本のラセンがみえる，b〜e，ラセンは 2 本にわれて，二つの色素體ができ上る，f，各々の色素體中に ラセンは數を垍す.

(原圖)

てれらの細胞は分裂して，1色素體をふくむよ 成し，しだいに葉の主要部分をつくりあげる。葉の始原の細胞中では, 色素體は白色體であり, はじめ圓 形であるが, やがて棒狀變つてから縱割型によつて二分し,さらに圓く變化する。

きわめて若い葉またはまを゙白色の若い葉の周邊部では，1まをは 2 色素體をるつ細胞の棒狀色素體が きわめて不規則形となり，ちぎれて多數の色素體をもつ細胞ができ上ることもある（圖 $\mathrm{g} \sim \mathrm{i}$ )。 


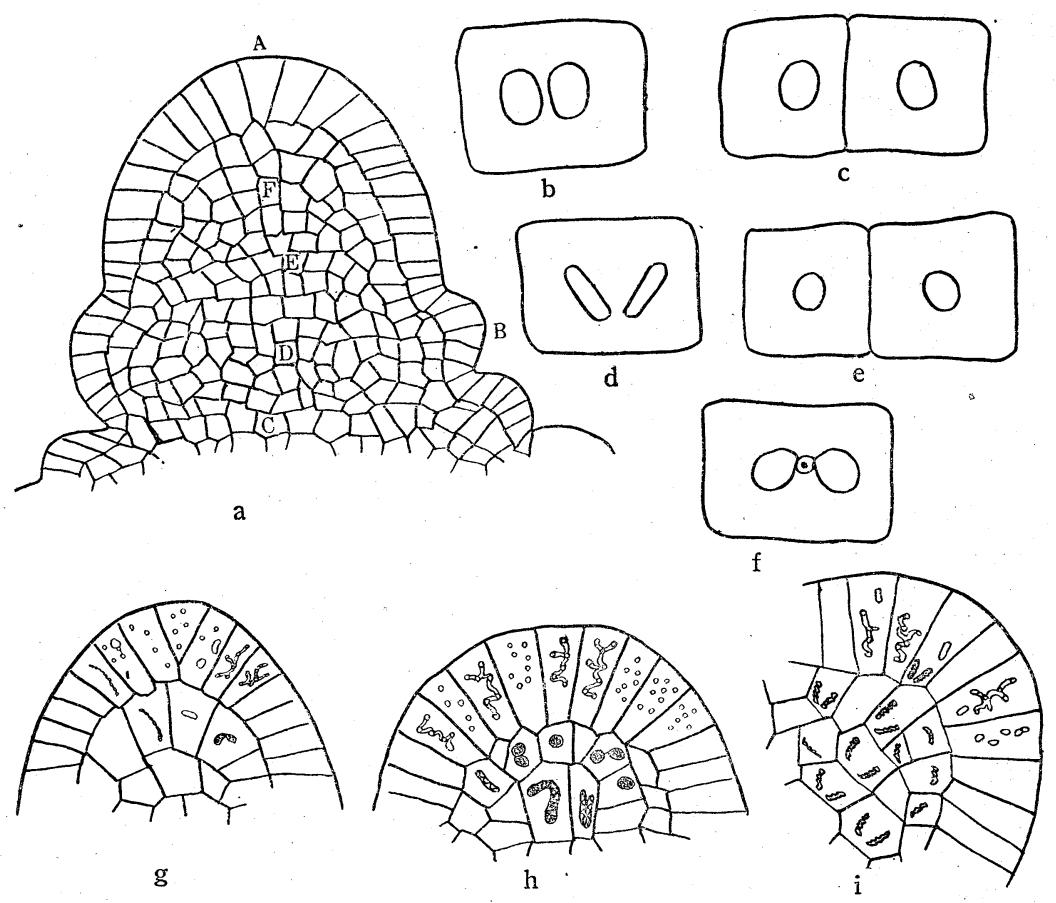

圖 9. a〜i. 葉の始原に扣ける色素體分裂. a, × ca. 170. b f, $\times$ ca. $700 . \quad$ g i, $\times$ ca. 130. b, a の $\mathrm{C}$ 部分附近の細胞の葉綠體分裂. $\mathrm{c}, \mathrm{D}$. 部分附近の細胞の色素體. $\mathrm{d}, \mathrm{E}$ 部分附近の細胞の葉綠體.

$\mathrm{e}, \mathrm{F}$ 部分附近の細胞の葉綠體. $\mathbf{f}, \mathrm{e}$ の狀態のつぎは, このよ5になる, g, 葉の始原の緣邊細胞 中で, 色素體がコンドリオン゙ーム狀の小粒に5つる狀態を示す. h, a の A 部分の詳細圖. i, a D B 部分の詳細圖.

（原圖）

かなり成熟した，またはほほとんど成熟した葉では，基部の細胞は多數の色素體をもつものが多く，畫 間はとくにある時間とい5限定は不明であるが, ほとんどつねと分裂時期にあるるのがみられる。また夜 間でも，20 時〜翌日 2 時以外の時刻にる，もちろん分裂を行つているととのある。

すでにのへたよらに，色素體分裂に三つの型を區別することがでをるが，てれら分裂の間に，綠ラセン は,どのよらに行動するであろらか。

まず，縱割型の場合には，綠ラセンが 2 本づつ接睢し，さらにそれらは接着して，1本のやや太いラセ ンとなる。この一次のラセンはのびて棒桀となる。この中に，二次のラセンがみえ，縱裂して 2 本となる (圖 10,0〜s)。

やがて，2本の二次ラセンは分離して完全な 2 本となるが，てのときまでに，葉綠體の基質も縱裂して 二つとなり，その各々の中に，それぞれ 1 本づつ綠ラセンが入って，てとに二つの棒狀色素體がでを上る (圖 10, $\mathrm{t} \sim \mathrm{x}$ )。 綠ラセンが分離するときには，ときに2本のラセンのからみ合つたキアズマ狀を呈するこ ともある。2 個にわかれた色素體中では，綠ラセンはそのまま止つていることもあるが，綠ラセンは綻裂を

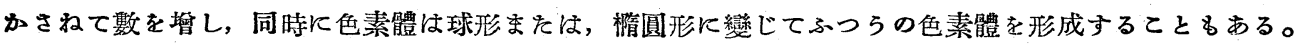

(圖 $10, \mathrm{y}, \mathrm{n}$ )。

縱裂した 2 本のラセンが分離するときに，その狀態を顯微鏡下にみるととるできるが，それらが 2 本 にはなれる速度は，かなり速い。縱割型の場合に，二次の綠ラセンがみえ，一次のラセンがのびのころに， 
二次のラセンも2 本に縱裂し, 一次のラセンはのび切つて, 短棒狀となつて 2 本の短棒狀體をつくるとる K，その中に 1 本づつ二次のラセンが入りてんで, 2 個の色素體ができ上る（圖 $10, \mathrm{p}$ w)。

このときはすでに一次のラセンはなく，2 個の色素體のそれぞれの中には, 二次の綠ラセンが一次の綠 ラュンとなつてみえている（圖10, w, x)。

圆 10, t から w Kらつるまでに, 二次のラセンがとけて一次のラセンが綎裂して 2 本になるのである が, 二次のラセンのとけるよらすは，生體のままで顯微鏡にみるととができる。

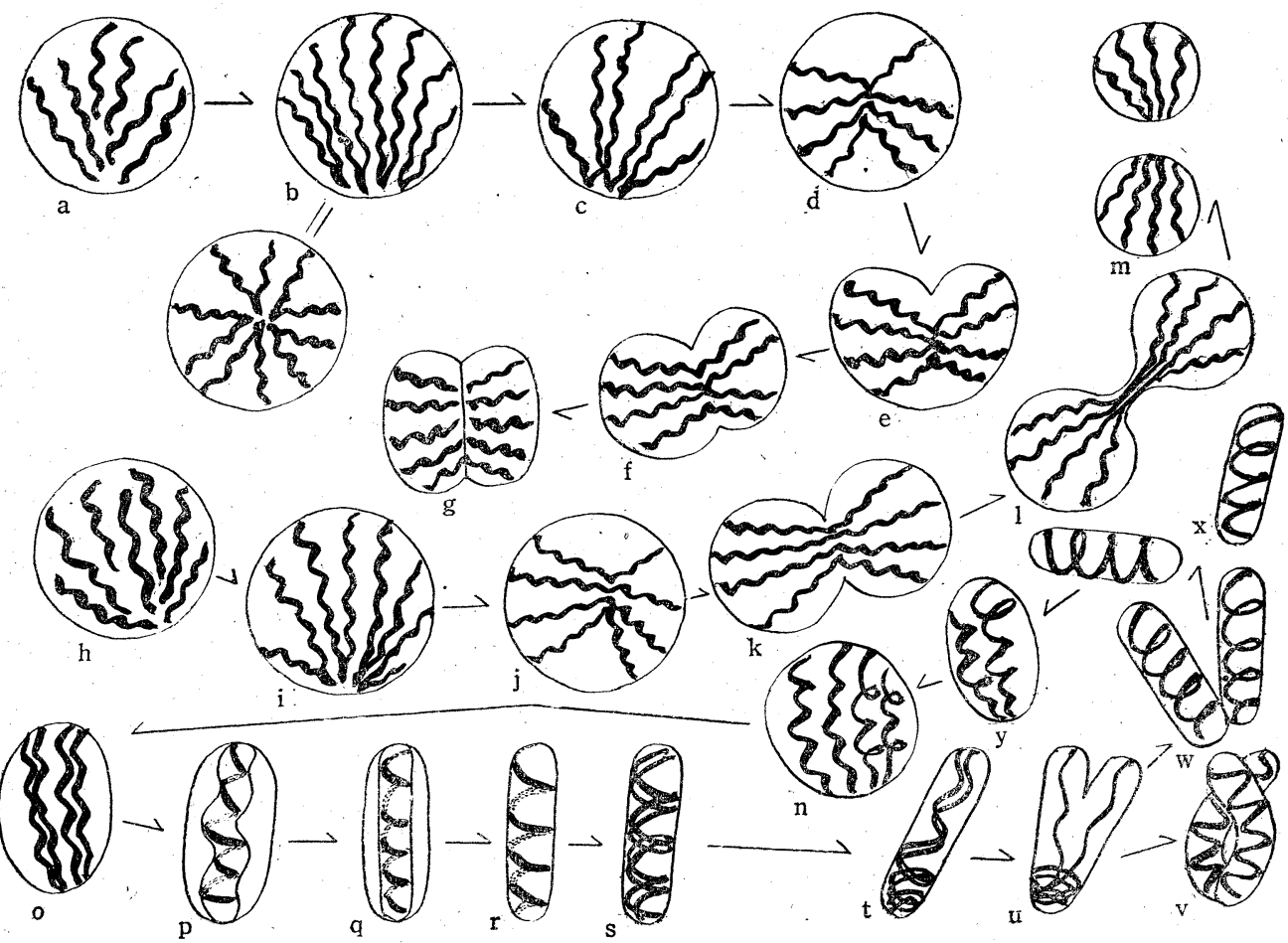

圖 10. 色素體分裂の模式圖. $\mathrm{a} \sim \mathrm{g}$, 二割型. $\mathrm{h} \sim \mathrm{m}, 3 \supset 5$ 型. $\mathrm{n} \sim \mathrm{x}$, 縱割型. （原圖）

この縱裂は生體で觀察すると60分くらいの短時 間である。そのよらすは，圖 11, a〜e まをは f〜jの よらであり，綠ラセンは，しだいにとける。

染色體のラセン糸が縱裂して 2 本になる場合に, ラセン系が部分的に回旋してねじれをもどして 2 本に なるのか，相關ラセンが回旋どとK切れてはなれ，ふ そにびつづいて附着するか問題があるが, 綠ラセン では、しだいKとけていくよらである。

この解抎は，綠ラセン自身の基質中の回旋による るのであるか, 基貿をともないつつとけていくるので あるか,ここにも問題がのこされている。

棒狀 1 色素體の細胞では, ‘色素體分裂は縱割型であり, 2 色素體細胞の場合は, 二割型で, 多色素體 細胞の場合は，圭としてふつら型である。

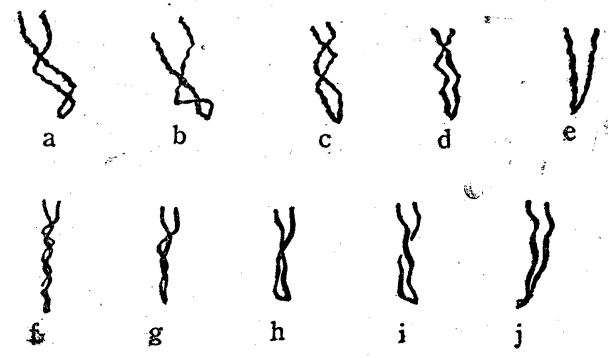

圖 11. $\mathrm{a} \sim \mathrm{e}, \mathrm{f} \sim \mathrm{j}$, 維割型火よる二次の センのをけ方. $\times$ ca. 1500. （原圖） 
二割型あるいはふつ5型の色素體分裂では, 綠ラセンの行動を直接追跡するてとは困難であるが, いる

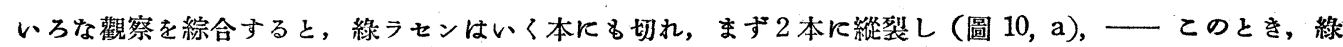
ラセンは、はじめからいくつにる切れるるのか,とのときに切れるるのか不明である——端部からひら き(圖 $10, \mathrm{~b} \sim \mathrm{c})$ ，中央部分でたがいに接して，接着部分を一束にあつめ；他端は開いているので，圖 $10 \mathrm{~d}$ のよ5Кなる。

やがて折曲つた部分が束にあつめられ，他端はしだいに開いて圖 10，d，のよ5Kなり，綠ラセンの開 いている部分から色素體基質に割れ目が入って葉綠體は二つとなり，二割型の過程となる。また，圖 10 , e〜f のとき，綠ラセンの開いた部分が兩方に引張られ，基質は兩側から等しくくびれとなり，亞鈴型とな つて,さらK引張られて 2 個の色素體となれば, これはふつら型である (圖 $10 \mathrm{~h} \sim \mathrm{m}$ )。

てのよらにして綠ラセンは，かなり規則正しく分離して二つの色素體をつくり上げるのであつて，で き上つそ二つの色素體のふくむ綠ラセンの量は, 大體同等になる。しかし，艮色素體の形の變化によつて， 後に, 綠ラセンの量に變化を生ずるるのと思われる。

色素體分裂を人第的に促進するために，次のよ5ないるいろの試みをしたが，まだ成功しない。

(A) 明るい場所から暗所にらつす：分裂速度に影響はない。前述のよらに，染綠體分裂中に，澱粉を蓄 積しはじめると，分裂を中止するものが多い。(B) 暗所から明るい場所にらつす：同前。(C) 室內か ら直射日光線の下゙に5つす：色素體は細胞膜の近くに移動。(D) $\mathrm{HCl}(0.01 \%)$ ：色素體はたがいに接 近して，長形の色素體は圓形となり，また，分裂は阻害される。（E) $\mathrm{HNO}_{3}(0,01 \%), \mathrm{HCl}(0.001 \%)$ ： 同前。 (F) $\mathrm{KOH}(0.01 \%)$ ：分裂速度中p速くなる。 (G) 醋酸, 蟻酸, 蓚酸の稀水溶液： いちちる しい變化はない。 $\mathrm{HCl}$ の場合に似ている。 $(\mathrm{H})$ 過マンガン酸カリ $(0.01 \%)$ ：色素體相互の位置はのば され，KOH と同じ結果となる。（I）オキシフル $(0.01 \%)$ ：葉綠體は圓形となつて，淁着する。（J） グリセリン（5すいるの）：分裂を阻害する。（K）菣糖（20\%）：原形質分離のよらな狀㦔，5すい 蕉糖水溶液では分裂速度は變化しない。（L）流動パラフィン：原形質分離のよらな狀態となる。色素 體は接筫する。

\section{4. 色素體とコンドリオゾーム}

ウラボシ科の植物であるホウライシダ, イヌワラビ, ヒメワラビ (Dryopteris oligophlebia var. elegans), オクマワラビ (Dryopteris uniformis), クサッテッ (Matteuccia struthiopteris), イワガネソウ (Notogramme japonica), ジゥモンジシダ (Polystichum tripteron), ハゴロモシダ (Pteris cretica var. albo-lineata), イノモトンウ(Pteris multifida) などを用いた。

材料を $0.1 \%$ ヤヌス綠水溶液で, スライド上で 20 分間染め檢鏡した。コンドリオン゙ームは淡青綠色に そまり, 色素體は染まらない, ときにヨード沃化カリ液, ズダン III の飽和アルコール溶液を用いた。

胞子：コシドリォゾームは小粒狀, 小棒狀, じゆず狀なぞの小體で, 數は多い。色素體はコンドリォ ゾームょりは大をく, 白色體で, その數は 3〜 5 である。

ズダン III のアルュール溶液で染めると, 油浻や液胞は明かにみえ, 白色體は多少, 粒状粠造で, コン ドリオゾームとは明かに區別される。胞子が，發芽に近ずくと，白色體は葉綠體とかわり，分裂によって 數を霄す（圖 12)。コンドリオゾームの數は、はとんぞ變らない。

したがつて，てのころからすでに，色素體とコンドッォゾームとは區別される。

前葉體：胞子が發芽して第 1 分裂をすると，その艮細胞中には，多くの綠色の葉綠體と小形のコンド yオン゙ームとがふくまれている（圖 13，A）。二つの形は明かに區別され，葉綠體は大形綠色で，コンドリ オン゙ームは小形で無色である。葉綠體は, その中に測粉粒をふくんでいる。

葉綠體は，種子植物の場合と同じ方式で，分裂する(清原 1935 ; 楠和よび川崎 1936) (圖 13, B, a〜e)。 1 例では葉綠體は亞鈴形となつた後，約 20 時間の中に分裂する。コンドリォン゙ームも二分法でふえるが，1 
細胞中のコンドリオゾームの數は，ほとんぞ一定している（圖 13，B，f，g）。

1 細胞の分裂が和てると, 細胞質中散在していた色素體ゆ コンドリォン゙ームは核分配像のますり反不覞則に散在し,中かて, 2 艮細胞中一, それぞれの位置にしたがつて, 分裂される。2 艮 細胞にふくまれてから，色素體もコンドリオゾームる分裂によつ て數を增す。

精子をつくるためと, 最初の造精細胞がつくられるとここの 中の葉綠體は數も少く、まれ白色體で, コンドทオン゙ームょりは 大形である。しかし，ときには，白色體とコンドリオン゙ームとが ほとんぞ同じ形で小さく，區別できないてとるあるが，ヤヌス綠 とよればコンドリオゾームは染色される。精細胞ができるを，中 はり数個乃至10個の白色體と多くの小形コンドリオン゙ームをるつ ている。これら二つの形の小體圢，ヤヌス綠で區別できる。

最初の造精細胞も精細胞もともと約 10 個の色素體と多くのコ ンドリオン゙ームをふくんで扣，分裂のををに，分裂して数を增 す(圖 $13, \mathrm{D}, \mathrm{a} \sim \mathrm{c}$ )。前葉體の細胞が卵細胞と藏卵器の細胞のる ととなると，色素體は白色體となつて形も小さい。コン゙ドリオン゙ 一ムと白色體は同じくらいの數で, 雨細胞にふく穼れている。細 胞のもとは 2 度相ついで分裂して, 腹㩐細胞, 腹溝細胞的よび卵 細胞となるが，とるに 10 個くらいの小形の白色體と, 多くの小形 で，粓狀，小棒狀，ビゅず狀のコンドリォン゙ームをふくんでいる (圖 13, E, a, b)。

精細胞：綪細胞中には 5 10 個くらいの色體と, 多くの小 形粒状のコンドリオン゙ームとがふくをれ, ヤ又ス緣の水溶液で區 別でをる。
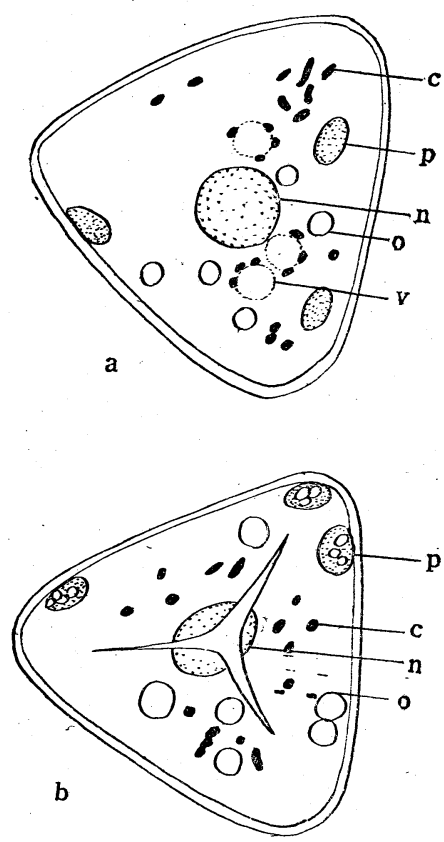

圖 12. ホウライシダの胞子. × ca. 1125. a, ヨード沃化カリ液 で染めたもの. $b$, ヤヌス絖り $0.1 \%$ 水溶液で染色したもの. $\mathrm{c}$, コンド yオン゙ーム. $\mathrm{n}$, 核. o, 油滴. $\mathrm{p}$, 色 素體. v, 液胞.

(原圆)

精細胞中の白色體は澱粉をふくんでいて, ヨード沃化カリ液で染まるが, 精子が成熟するにつれて, 測 粉は大形となり，したがつて白色體る大形となる(圖13，F，a～f)。數はほとんぞ變わりなく5〜10個く らいで, コンドyオン゙ームは明かに區別される(圖 13, F, g〜1)。

コンドリオン゙ームは精細胞から精子完成まで，ほとんど數は變りなく，やがて精子ができ上ると，色

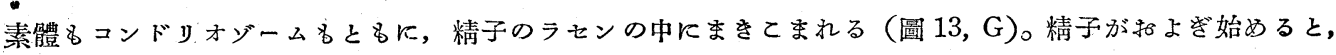
色素體やコンドリオン゙ームは細胞質とともと精子のからだのまわりとついて扣り,やがて精子の感な運動 中にすてられる。ときとコンドリオゾームは, 精子の生毛帶の上にならんで, ちよらぞ緎毛の基粒の上5

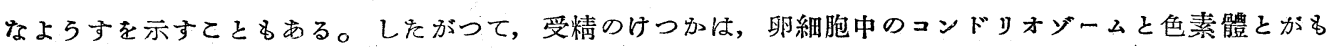
ととなつて，造胞體細胞の色素體やコンドリオン゙ームができてくる。

畉細胞：“若い卵細胞中には，約 10 個の白色體と小形コンドリォン゙ームとがみられる（圖 13，H）。雨 者は形で區別できる。色素體は球形で, コンドリォゾームは精状, 小棒狀, ビあず狀で, コンドリォン゙ー ムは色素體より多少, 小さい。完成した蝠細胞中では, 約 10 個の球狀白色體と多くの小形粒狀のコンドリ オン゙ームとがある。雨者は, 受精のときに,そのままこつている。受精卵中では, 白色體はしだいと綠 色となり，第 1 回目の分裂まえに葉綠體となる。てれらは，自由に配列され，分裂によつて數を䝬してい ২。

造胞體：造胞體では，色素體々内部の組織，地上茎，根托よび假根をのぞいてすべて葉綠體で，二分 


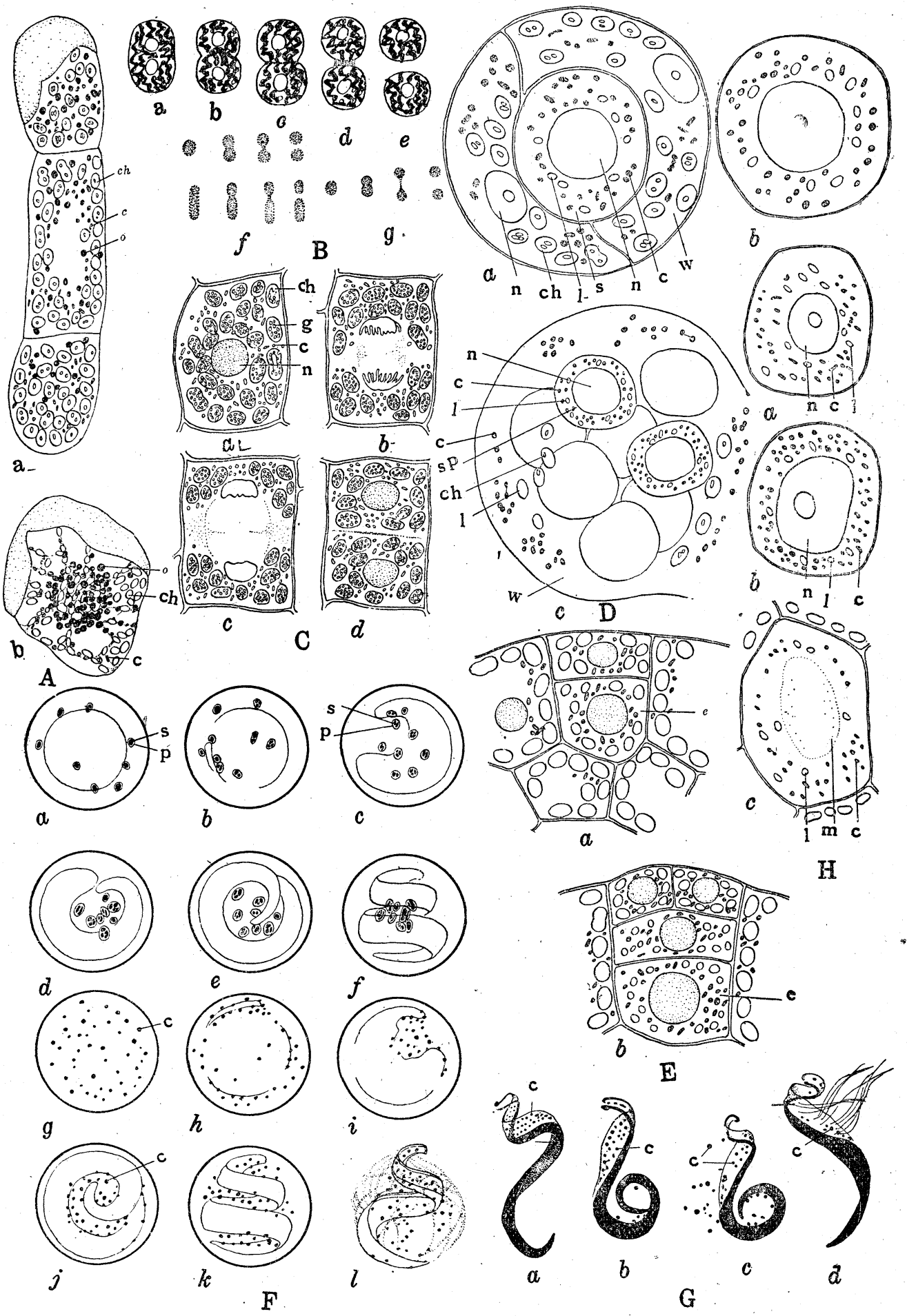


圖 13. A, ホウライシダの發芽した胞子. $\times$ ca. 357. a, コルヒチンの $5 \%$ 水溶液中で發芽したもの. b, コルヒチン $0.01 \%$ 水溶液中で發芽したもの. c, コンドリォン゙ーム. ch, 葉綠體. B, a〜e, ジウモン ジシダの前葉體細胞中の葉綠體の分裂， $\times$ ca. 1000. f, g, ジウモンジシダの前葉體細胞中のコンドy オゾームの分裂 $\times$ ca. $1000 . \mathrm{C}, \mathrm{a} \sim \mathrm{d}$ ，ホウライシダの前葉體細胞の細胞分裂. $\times$ ca. 540. c, コンドリ オン゙ーム. ch, 葉綠體. $\mathrm{g}$, グラナ狀の綠ラセン. n, 核. D, 造精細胞と藏精器. a, ホウライシダの若い 藏精器. $\times$ ca. 1000. b, 同, 最初の造精細胞. × ca. 1000. c, クサソテッの藏精器. $\times$ ca. 1000. c, コン ドリオゾーム. ch, 葉綠體. 1, 白色體. $\mathrm{n}$, 核. $\mathrm{s}$, 最初の造精細胞. sp, 精細胞. w, 藏精器の方ぶの細胞. E, 若い藏卵器. a, ホウライシダの畉細胞のはじめ. × ca. 540. b, 同, 若い卵細胞(e). × ca. $460 . F, a \sim b$, ホウライシダの精子完成過程中に扔ける色素體. 多少模式的に示してある. p, 白色體. s, 澱粉粒. $\times$ ca. 1600. g〜l, 1ヌワラビの精子完成過程中のコンドリォゾーム.ヤヌス綠の $1 \%$ 水溶液で染めたもの. c, コンドyオゾーム xca. 1600. G, a〜d, コンドリオゾームと精子：a, b, ヘマトキシリで染めたクサソ テッの精子. × ca. 1400. c, d, 同, ヒメワラビ. × ca. 1000. c, コンドリォゾーム. H, a c, 卵細胞. a, ヒメワラビの若い卵細胞. X ca. 750. b, 同, 完成した卵細胞. × ca. 1500. c, 同, 胚の第 1 分裂. c, コン ドリォゾーム. 1, 白色體. $m$, 核分裂像. $n$, 核.

（原圖）

法でふえる。コンドリォゾームは, 小粒狀, 小棒狀, じゆず狀で, その形の小さいてとで, 葉綠體から區 別できる。地下荎, 根, 假根では色素體はひどょらイ形となることがある。

胞子玹成：造胞細胞は，5１0 個の白色體と多くの小形コンドリオジームをふくんでいる(圖 14)。最 初の造胞細胞が成熟すると, 色素體はしだ、に小形となる。數回の分裂の後に, 多くの胞子盘細胞がつくら

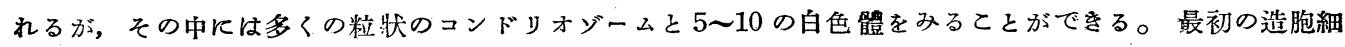
胞中の色素體は, コンドリネゾームょりは多少大きい。最初の造胞細胞の分裂によつて生じる胞子母細胞 は,すへててみ，最初の造胞細胞と同じくらいの數の色素體とコシドリオン゙ームとをもっている。

胞子母細胞の減數分裂第 1 分裂火，色素體やコンドリオン゙ームは中期には赤道板の附近にあつまるが， 後期，終期には，しだいに細胞板の中心部分に向つて入つていっていく。細胞板が赤道面の中央から周邊 部につくられるにしネがつて, 色素體ゅコンドリオン゙ームを二つの艮細胞に分配する。第 2 分裂になると,
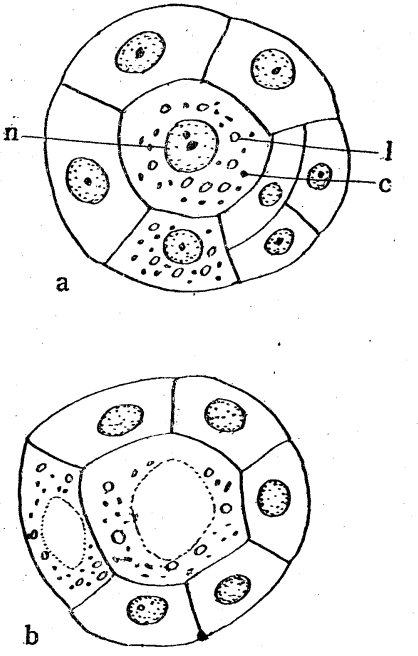

圖 14. a, ハゴロモシダの最 初の造胞細胞. $\times$ ca. 240. b, 同, 最初の造胞細胞の第 1 分裂、 $\times$ ca. 240. c, コンドリオゾーム. 1, 白色體. $n$, 核. (原圖)

第 1 分裂と同じようにして, 色素體やコンドリオン゙ームは, 四つ の胞子細胞にわけられる(圖 15, e, f)。

胞子細胞中では，胞子の成熟にとるなつて，色素體（白色體） は，しだいに犬きを霄し、コンドリオン゙ームから區別できる（圖 . 15, g)。
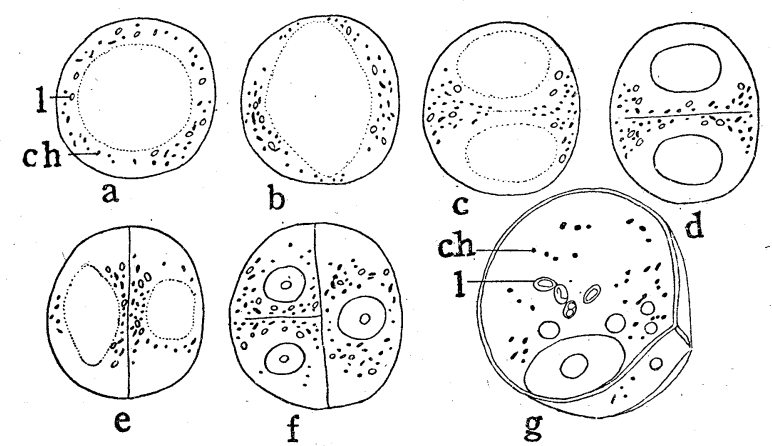

圖 15. $\mathrm{a} \sim \mathrm{d}$, ジウモンジシダの減數分裂の間の色素體とコンド yオゾームの行動. $\times$ ca. $1000 . a$ ，ディアキネシス期. b, 中期. c, 後期. d, 終期. e, 第 2 分裂の中期. $f$, 第 2 分裂の終期. $g$, ホウラ イシダの若い胞子. ch, コンドyオン゙ーム. 1, 白色體. × ca. 500 . (原圖) 
最初に述べた 5 と, ヤヌス綠で生體染色される粒狀, 小䏾狀, ビゆず狀の小體をコンドリォゾーム となずけるとそそれらはつねと、・ラボシ科の生活史の全時期に通じて,つると區別できる(圖 18)。

\section{5. 色素體の分配}

コンテリクラマゴケでは, 莁の細胞の大部分は, 多色素體の細胞で, 葉の上面表皮の細胞は, 2 葉綠 體, 下面表皮は多葉綠體の細胞であり, 內部の細胞 2 は葉綠體で, 葉 のーりは 1 層の細胞から成り, ての葉緣の細胞の中とは, 多數の葉綠體 がふくはれている(圖 16)。

葉の頂端細胞が分裂してのびるときとは, 細胞分裂と先立つて, 色 素體は縱割型の分裂をし, 二つとなつてから細胞も二分して, 各細胞は 一つづつの色素體をふくむよらとなる。したがつて，ての部分は細胞は つねと, 1あるいは 2 色素體をふくみ, しかも, その型は棒狀である。 てのよらな狀態の細胸中, 莖の細胞となるるのは, そのまま, 樁狀色素 體が球狀となり，二割型まをはふつら型によって分裂して多色素體と なる。

葉の原基の細胞は, 茎の頂端の細胞と同じょうに 1色素體の細胞で あるが, 縱割型によつて盛に分裂し, 分裂中の細胞は, つね权1またわ 2 色素體の狀態であるが, 分裂を停止した細胞は, 2 色素體とななり, そのまま葉の內部細胞を檏成して,つねに 2 葉緣體としてとぞまる。ま た, 表皮をつくる細胞は, 原基の 1 色素體細胞の分裂によつてつくられ た 1 色素體細胞が, 細胞分裂を停止して後, 上面・゙は 2 , 下面では多色 素體となつて，表皮細胞となる。

ときと, 葉の內部の 2 色素體の細胞は, それぞれ二割型によって二 分して 4 色素體となり, 細胞分裂の後, 2 色素體つ゚つをふくむよ るとともある。4色素體となつた後に， 3 と 1 の色素體をふくさよ 5 K なつたときとは, 3 色素體の方は, 細胞分裂と色素體分裂とによつて 2 色素體をるつ 2 細胞となり，1色素體の方は，色素體分裂によって，2 色素體となる。したがつて, 葉の內部細胞は, つねと 2 色素體としてと ぞまる。このよ5にして，盛に細胞分裂する部分はつねと 1 2 色素體 の狀態であり,これらが葉の一定部分 (表皮, 内部組織) の權成成分を してきめられると, 細胞分裂を停止して, 色素體のみ, 分裂し, 内部で は 2 色素體として止る。元來, 1 色素體の始原狀態の細胞が, 機能に應じて 2 まね多色素體の狀熊に變わ るるのである。この祭, 同一組織內で色素體の數の異常かできた場合とは、すぐ調整が行われて,つねと 同一色素體數をるつよらとなる場合が多い。

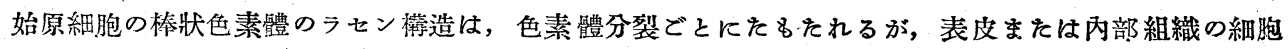

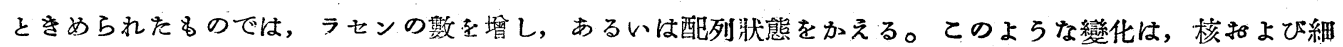
胞質との關聯に扣いてなされるのであろらが, 元來, 色素體住細胞質との關聯に和いて光合成を行い, ま そ, 細胞の狀態によつて葉綠素の量の增減するなぞ, 細胞質的の影響が多いるのであるから, 上述の色素 體の狀態の變化は, 細胞質のある因子によつてきとして支配され, てのよ5な因子は, plasmagene と總 稱されるるのと一致するるのではなかららか。 
茎の一部から新しく葉を生ずるととがある。このような場合には，永久組織の一つが細胞分裂して， ての細胞は 1 をは 2 色美體以上るふくむよらになり，2色素體以上をふくむよらとなつた細胞は，しだ いK細胞分裂して, ついK1色素體の原始分裂組織の細胞狀態となつて, 細胞分裂とともに, 葉を形成す るよ5になる。このよ5に色素體は分裂していくが, ラセンの行動は前述のよらに規則正しく, 色素體分 裂の直後には，つねと 2 色素體は等しい潔造をもつて和り，細胞分裂の後にも，そのふくむ色素體數が同

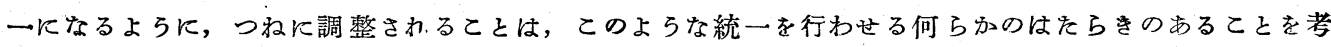
えさせ, てれを plasmagene とよぶこともできるであろら。これらの色素體の行動は, 核の行動とよくに ている。

色素體の分裂扣よび分配の規則性は，タチクラマゴケその他のイワヒバ屬（Selaginella）に同じよ.5 Кみられるが, イワヒバ (Selaginella involvens) なぞは觀察が困難でむり，イワヒバ以外のシダ植物ゅ 種子植物では, しだいK不規則となつている。

コンテyクラマゴケでは胞子ができにくいので, 胞子發芽, 精子ゅ, 畉細胞形成, 受精などのよらすを しららへることはできないが，タチクラマゴケ（Sel. Savatieri）あるいは，イワヒバなどの研究を綜合する そ,つぎのよらに色素體の行動を推定することができる。イワヒバでは精子の尾端に 3 個のだえん體形の 小體が 1 列について扣り，未決定の性質をもつているが，その精細胞中の狀態から，白色體にふくまれた 炭水化物あるいは色素體と考えられるが，てれは精子の運動中にすてられる。したがつて，精子は受精の ときには，細胞質的の部分をともなわないで，卵細胞中に入るるのと考えられる。

イワヒバゃタチクラマゴケの眲細胞は 1 色素體をふくむ。精子は色素體をとるなおないから，受精卵 細胞は卵細胞に由來する 1 色素體をふくむのみ である。したがつて，ての發芽によつて生ずる 新しい植物は,その色素體をつねと母方からら けついでいるのみである(圖 17)。

タチクラマゴケでは, てのよらな 1 色素體 の細胞は縱割型の分裂によって, つねと 1 色素 體の細胸をつくり, したがつて, 分裂組織の細 胞は, つねに 1 色素體である。1 色素體が分裂 して，2色素體となると，細胞分裂がつづいて 和てる。やがて葉が形成されると，表皮，葉緣 の細胞は多色素體であり, 葉の內部細胞は 2 色 素體である。

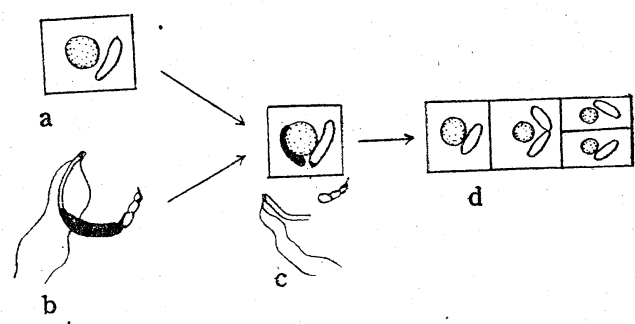

圖 17.クラマゴケの受精に和ける色素體分配 模式圖. a, 卵細胞. b, 精子. c, 受精. 精子小核 のみ卵細胞中反入る。 d, 受精卵細胞の分裂.

(原圖)

タチクラマゴケ, コンテリクラマゴケの分裂組織は 1 色素體細胞で, 色素體をみると, 前者では柸狀 色素體中にたてに 2 3 本の綠ラセン, 後者の場合には 1 本の綠ラセン てれらの場合は, 白色體であるか ら，綠色ではない。ときにわずかに綠色のととるある）がみられ，色素體のちが、がみられるが，完成し そ組織の色素體では, 兩植物の間に區別がみられない。また, 色素體のはたらきについて子, ほとんどち がいはないよらに思われる。しかし，ちがいがあるとすれは，㪲方に由來した色素體のちがいKよるるの であり,また, palsmagene Кよつて支配される點も多い。

したがつて，色素體について乫然變異を和てさせようとすれば，卵細胞または受精畉などの變化を扱 こさせればよいことになる。色素體が核の支配をどの程度に5けているかといらととは興味のある問題であ り,ての點については，研究を將來にゆずる。 


\section{6. 論議}

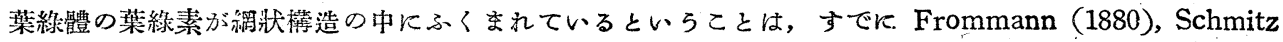

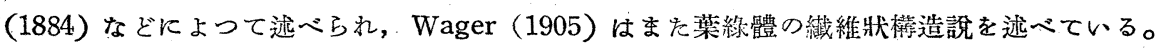

著者はすでに $(1940,1940,1940)$, 生體觀察, ヨード沃化カリ液,ヤヌス綠液, エォシン液による觀

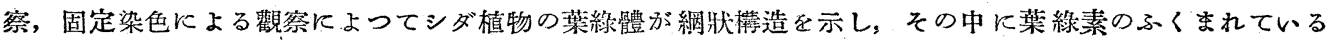

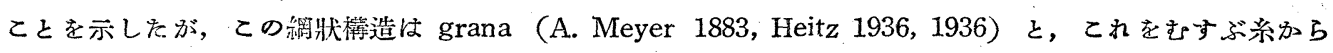
成ると考えられた。しかし，その後の研究によつて，系は實は不規則なラセン糸でその步みは長短いる

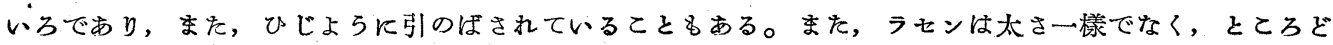
てるにふくらみをるつている。

この丵造は，核が䉼狀構造とみえても，實はラセン糸のあつまりであるのと全く同樣である。固定し そもの, 固定染色したもの, 生體のものとついてる, 結果は同一である。

葉綠素の周圍には Bredow (1891) と上れば, plasma membrane があり, Senn (1906) とよれば fine membrane があるといら。まを，著者 (1940) も，葉緣體の周圆には， thin membrane があると考 えそが，醋酸カーミン・プレパラートで，内容が收縮して外部にらすい膜ののこされている事賽や，黑線 のみえる事實などからみて, 葉綠體の外周は, 內部よりやや維密な原形質があり, 原形質的の膜 (plasmic membrane) となつているものと考元られる。

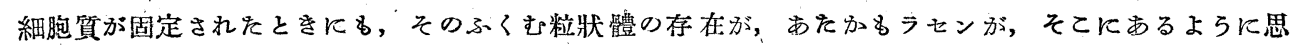
わせる場合がある。しかし，これは單なる光學的虛像てあつて，實際は糸ではない。しかし，綠ラセンの 場合は，不規則化ま淡綠色のラセンをみとめるととができる。

從來, シダ植物の葉の葉緣體が一樣にみえるといわれた場合は; 溊粉粒の䝪藏のために綠ラセンのみ

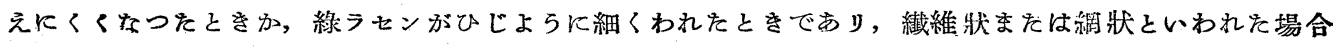
は，綠ラセンが正しく見られなかったときである。Grana と綠ラセンとの關係については，後に論じる。

Menke 括よび Kogdl (1939) が, ッンゴケ(Anthoceros punctatus) で膜狀構造をみ, Kausche fo よび Ruska (1940), Ardenne (1940) が葉綠體け膜狀搆造のあつまりで, grana す膜狀構造に和和わ水 ているとしたのも賽は, 綠ラセンがさらと細く縱裂した場合, あるいは綠ラセンそのものであると考兄ら れる。Granick 和よび Porter（1948）は，電子顯微鏡で grana の部分には小粒子があつまりそその間にま れ小粒子の散在しているよらすをみているが，てれは綠ラセン上の粓狀部（grana）の部分では小粒子が多 くあっまりその間に少數の小粒子がならんでいるょらすではないかと考元られる。

Heitz (1936, 1936) は多くの樎物の葉緣體に granaをみ, てれが色素體一ぱんのっくりであると考 えられたが, 著者は色素體のつくりの一樣とみられるるのる綠ラセンのふくらんだ狀態か, 細くわれた狀

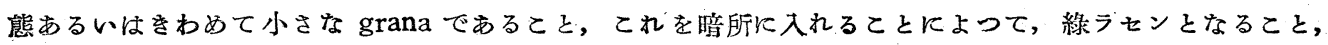
天然に綠ラセンと grana 狀態ををは一様掅造との間に可逆的變換のあるてと, grana と綠ラセンの變換の 途中では, grana が細長くなり，細い糸でつづけられている狀態のみえるてと，また，てのよらな狀㮩を ふつらとするもののあるてと，人的篇飞基質をふくらませて，綠ラセンをみるよらにできること，基質を

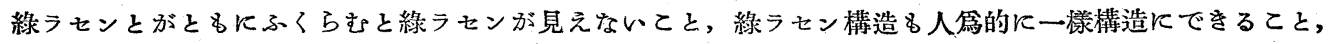
凝固させると綠ラセンの見えてくるてとなどの事實から，綠ラセン構造は，色素體が可逆的凝固の狀態に

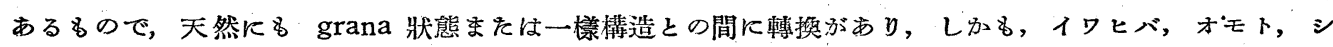
ダ植物のよらに，つねと綠ラセンを示するののあることからみて，色素體の基礎構造は綠ラセンで，種に より，條件炡って，grana 狀を呈すると考元た方が妥當であると思われる。

色素體が規則正しい分裂の行動を示寸場合がみられ, 分裂の型もつくりるかなり核と似ている場合が 
あるのであるから，Muller（1947）のいらょらに，核中の染色體中にできるまえの狀帢の遗傳子と色素體 とは，共同の租先をるつるの，あるいは，核と色素體とは同じ訅原をるつものと考えられる。

いろいろの試藥によつて, 人局的に色素體の grana 狀, 綠ラセン狀, 一樣構造がつくり出されるが,

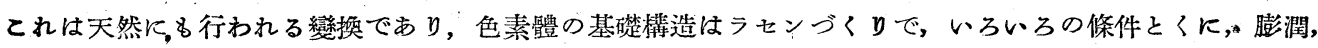

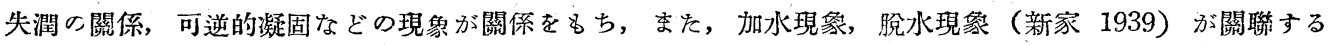
と思われる。

シダ植物では一ぱんに綠ラセンをみることができるが（著者 1944），綠ラセンは必ずしもコイル狀に はみえないるので，むしろ引のばされた形であり，ねじれて引のばされた紎體とみえる場合るあり（ム

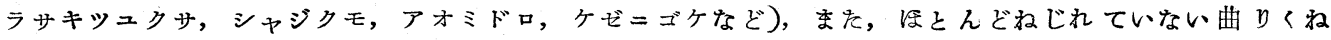
つそ糸狀體であることるある (Jungermannia, シャジクモ, ヒルムシロ螿など)。

シダ植物以外のものでも，多くの場合に綠ラセンがみえるよらであり，ときに一栐にみえるような場 合にる，日かげに入れて和くとみえるよ5になる。おた，同一植物でも條件によつて緣ラセンがみえるこ ととみえないてととがある。

酸やアルカリトよつてる綠ラセンはみえるよ5Kなるが，ての場合は葉綠體は死妨あ゙あから，綠 ラセンがみえるよらになつたのは，この場合は非可逆的の㠜固である。

一方，日かげにあつて，しかも原形質流動の盛な葉綠體に綠ラセンがみえるてとがあり，また，綠ラ センのみえないときる $0.1 \% \mathrm{KOH}$ をはたらかせて可視にするてとるできる。コンテックラマゴケでは, ア ンモニア處理によつては，葉綠體は變化しないが，0.1\% KOH で處理すると，しだいに綠うセンが明かと なることは，葉綠體の基質はアンモニアによつてふくらまず，KOH によつて基質がてわされて、綠ラセ ンのみが明かにみえてくるるのと推定される。

一羕にみえていた葉綠體が，綠ラセンを示すよらになるのは，元來そのよ5なつくりがあつて，綠 セン自身の膨潤によって不可視の狀態になっているからで，綠ラセン自身が失潤すると，みえるょ5にな ると考えるか, あるいは，元來，一樣に色素が分散していて一樣にみえたるのが，日かげに入れたり，武 薬をはたらがせたりしたてとによつて，ラセンづくりを示すよらになると考えるか，あるいはまた，一眭 的に凝固してラセンづくとなるかの，の三つの場合が考えられる。

‘しかし，つ称綠ラセンを示して，ラセンづくりをるつるのもあり(コンテリクラマゴケ，オモト， その他), てれらの場合, 綠ラセンの部分が基質とちがつた性質を示すことかるみて, 葉綠體中に元來, ラ センづくりがあると考える方が晏當であり，また，一時的の綠ラセンは㠜固すると考えるととは，葉綠體 中にてのよ5な凝固のよ5すを示すつくりがあるてとを肯定するてとになる。

Weier $(1936,1638)$ は, サトウダインンの葉綠體で, 日あたりにあつた葉や若い葉では, grana がみ えるとして，葉綠體づくりの變化しらるととを述へている。また，Liebaldt (1913)は，葉綠體は hydroidphase と lipoidphase とから成り，後者は乳濁液樣に前者にふくまれ，顯微鏡的に制定できないが，表面

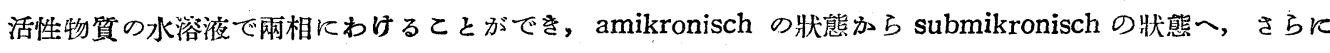
mikronisch 飞變化し，滴狀分離と色素滴をつくるとしている。

Strohmeyer (1935) は，優渗壓をたは劣滲壓の溶液によつて，脫水ををば加水を把てさせて，核內構

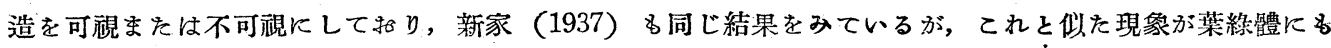
指こるのであつて, $\mathrm{NH}_{4} \mathrm{Cl}$ 水溶液によつて綠ラセンがふくらんで一栐づくりになり，5すいアルコール， フォルマリンその他によつて綠ラセンがちぢんで，可視となり，固定液によつて凝固してもみえるよ5に なりまた，シャジクモなどの原班質流動の盛な明かに生きている細胞中の葉綠體が, 天然に綠ラセンの ふくらみとちぢみを示して不可視あるいは，可睨となるととなどから，葉綠體は元來，綠ラセンのつくり があり，とれがふくらみとちぢみとによつて不可視あるいは可攽になる場合もあるものと思われる。 
Sachs (1862, 1863), A. Meyer (1883), Wager (1908), Doutrelinge (1935), Weier (1936), Heitz $(1936,1936)$ は, grana が葉綠素をもつ部分であるとしたが, コンテリクラマゴケ，オモト，ムラサキッ ユクサなどでは, grana とみえる場合るあるが，實は綠ラセンの光學的斷面であつて，顯微鏡のネジの上 下によのて，相互の連絡がみえる。まを，溉粉粒が菜綠體中に多数つくられるとをは，葉綠體をつぶすと， 澱粉粒はつぶつぶとなつて出てきて, grana が和し出されたよ5反办えるが賽は，grana は綠ラセンの一

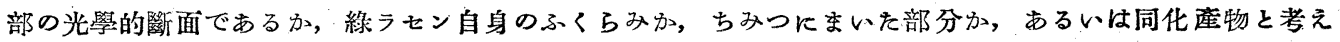
られる。

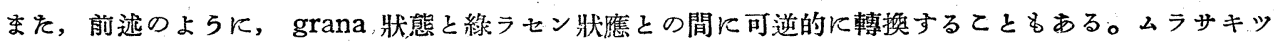
ユクサやホウライシダは葉綠體が膨潤してふくらみきつて, 綠ラセンが綠色のかでのよ5な狀態になる場 合があつて, 葉綠素は綠ラセンにふくまれるてとを示している。綠ラセンは必ずしる一栐な紎體ではな

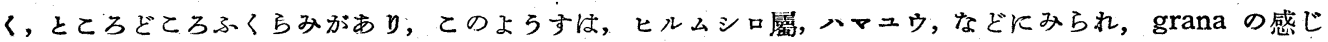
をるたせるが，實はラセン糸のとくべつな構造である。

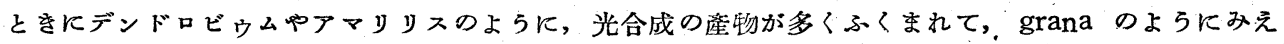
るとともある。

色素體の觀察方法としては, 從來, 生體觀察の活かと圭として Heidenhain 鐵明警染色法が用いられ ていたがその活が Kolatschev 法 (1916), Hirschler 法 (1915), Weigle 法 (1915) などがあるが, いずれもパラフィン法によるものである。著者はパラフィン法を用いず，固定染色して totalpreparation とし, 生體の totalpreparation と此較研究した。てれらの方法は有效であつた。

また, $\mathrm{NaOH}, \mathrm{KOH}$ あるいは $\mathrm{HNO}_{3}$ などとよつて葉綠體の基質を破壞してラセンをみるととる試み

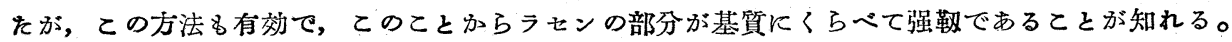

葉綠體中飞蛋白質の結晶のある場合が，イワヒバ屬について知られているが，著者の觀察によれば, こ の結晶樣體は必ず細胞中の 1 葉綠體に限られ, 綠ラセンと連絡しているととがある。をを, 葉綠體分裂に 際して, 一方の艮葉綠體のみと入るととる明かとなり，ての小體と葉綠體の分裂とは何かの關係をるつよ 5と思われる。清原 (1926) はク口モ（Hydrilla verticillata）の葉を水中に封じて觀察し，楠和上び川崎 (1936) はイワタバコ（Conandron ramondioides）和よびスヌキモ（Utricularia vulgaris）の葉を水中で 觀察して色素體の分裂をみている。また， Reinhard（1933）は，コケ，スギナ，顯花植物の葉をKnop 液, Knop 寒天，ぶビら糖なぞの 0.5，1〜2\% 水溶液中で觀察し，8〜10 日間生存するてとをみている。 著者は材料を井戶水, ときと蒸溜水, 水道水で觀察し, 細咆の生死は, ブラウン運動の有無, 原形質分離 からの恢後，葉綠體の移動，分裂なぞから制斷した。ての方法によつて，2 日以上生活させ得る。 る。

サンショウモ（Salvinia）の水葉の毛の中では，色素體が退化して小形となつてしま5てとがあると， Cholodny (1923) とよつて報告されているが, 著者の研究では, 葉の基部の多色素體の細胞から 1 乃至 2 色素體の細胞に5つるときと細胞中に退化色素體が觀察された。色素體の分裂とついては, 古くは Nägeli (1863), Kny (1897), Sachs (1875), Strasburger (1880), Haberlandt (1882, 1888, 1905), Schmidt (1882), Neměc (1910), Scherrer (1914), Carter (1919, 1920), Heitz $(1922,1925)$ などの研究があ $\boldsymbol{y}$ ，大體，二分法飞よって拾殖するととが知られたが，二分法についての確固たる證據は缺けていた。し かし，1926 年と淸原がクロモて同一色素體を追跡し，分裂をたしかめ，つづいてMa (1928), Senjaninova (1928), Stone (1932), Reinhard (1933), 楠括よび川崎 (1936)などの研究となつた。 Stone (1932) な ぞは，細胞貿の一部がしだいと凝縮して色素體飞變わるものであるとしている。色素體の分裂の研究とと

もと，色素體とコンドリォジームとの相同の問題が引和てされたが，との閴題については，前述した。 著者は色素體の分裂型として，ふつら型すなわち，ふつらの二分法の他に，二割型的よび綎割型を區 
別するととができた。說明はないが，二割型は Haberlandt (1888) のイワヒバ屬の論文, Scherrer (1914) のッノゴケの論文にるみつけるてとがでをる。縱割型は Scherrer (1914) のッノゴケの論文中に見出すて とができる。1色素體が二つに分裂しつつある途中で，てれと直角な分裂軸をるつて第 2 の分裂の和てると とがあり、このよ5な現㣇は，Stone（1932）が觀察している。色素體分裂に要する時間について清原 （1926）は，朝分裂が和こりはじめ，夜の 8〜11時に急にくびれ出し，夜中の 1 時ころに分裂を終り，粎 20 時間を要するとしている。また，楠扣よび川㟢（1936）はある場合に，タヌキモ (Utricularia vulgaris) まよびイワタバュでは，16時間牛以上を要するてとをみている。てれらの時間は，もちろん色素體內外の 條件によつて左右されるるのであるが, 著者の場合には, ふつら型は 14 時間, 二割型は 12 時間, 縱割型 で綠ラセンの縱裂に 30 分くらいを要した。とれら色素體の分裂に，綠ラセンが規則正しく行動することが みられ，とくに縱割型の場合には綠ラセンの行動の規則正しさがみられた。

著者はすでに（1939）に，ウ ラボシ科の生活圈中に精子は,そ の色素體とコンドリオン゙ームとを すて去り，受精卵は，卵細抱の色 素體とコンドリオゾームをもつて いるのみであるとしkがすずに 1914年 Scherrer はッノゴケの留 細胸は 1 色素體で，造精細胞には コンドリオゾームは多少みられる が，色素體はみられないとしてい る。イワヒバの場合にる, 色素體 は母方のむのに本來すると考えら れる(圖 18)。

したがつて，色素體の遺傳は， 母系的であるが, 受精畞から發育 した植物體の細胞中の色素體の行 動やっくりは, plasmagene 和よ び核の影響をらけるとととなる。

Senjaninova (1928) $の C a$ tharine undulata, Physcomitrium

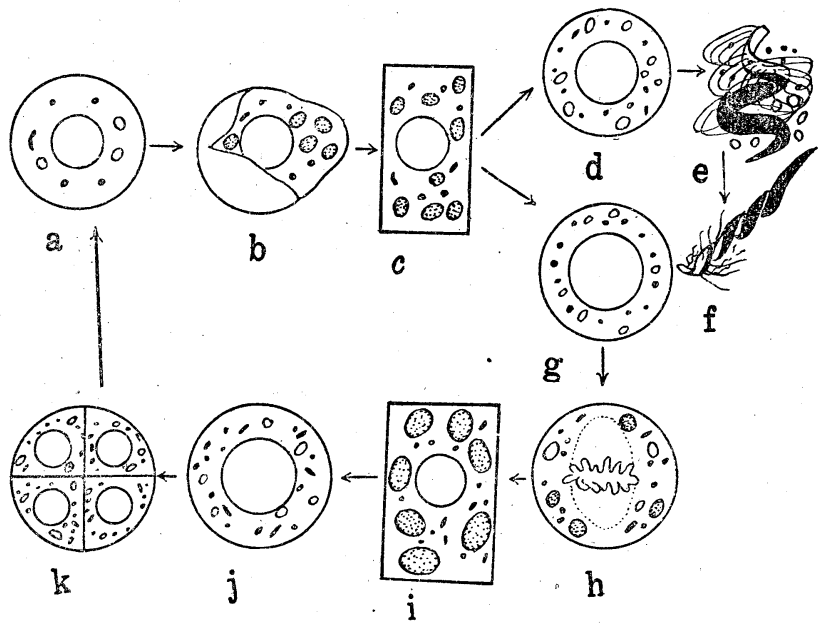

圖 18. ウラボシ科植物の生活圈中の色素體とコンドリォゾーム の行動模式圖. a, 胞子. b, 發芽した胞子. c, 前葉體細胞. d, 精細 胞. $\mathrm{e}$, 精子. $\mathrm{f}$, 藏畉器中の精子. $\mathrm{g}$, 卵細胞. $\mathrm{h}$, 肧の第 1 分裂. $\mathrm{i}$, 造胞體の葉の細胞. $\mathrm{j}$, 胞子母細胞. $\mathrm{k}$, 胞子細胞. 白い小球は白色 體, 點をらつた小球は葉綠體, 黑い小粒はコンドリオン゙ーム。

（原圖） piriforme К招ける研究は, 多色 素體の細胞せ胞子をつくる細胞分裂中と色素體數を減じ, 胞子母細胞では 1 色素體となり，胞子中では 1 色素體であるが，受精卵では多色素體である。このよ5な分配調整は，核よりむしろ細胞質の影響をう け, plasmagene.とよるものであるら。

高等植物の色素體の中には，色素體自身の力によつて行動するるの, 一部，核のはをらきをらけてい るもの，核のはたらをの外よつて行動するるのがあるとは，すでに今井（1936）の述へているとてろで あるが，てのよ5な色素體の行動が，ぞの程度まで，核の支配をらけているかを決定するてとが必要であ る。植田 $(1949,1949)$ は葉緂體の光合成の能力は核や細胞質の影響を5けていないが，葉綠體と細胞質と の相關性は,な和研究の要があるとしているから，葉綠體の分配も主として細胞筫の影響によると思われ る。 


\section{摘 要}

1）シダ植物の葉綠體は，基質とその中にふくまれた綠ラセン（green spiral）とからなり，基質の外 图はらすい原形質膜につつまれている。綠ラセンは不規則に趈旋し，多くはそその上にふくらみをるつ糸 で, この中に葉綠素がふくまれている。白色體 (leucoplast) 和よび有色體 (chromoplast) も, その中に

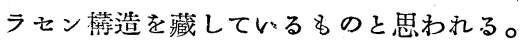

2）シダ植物以外の高等槙物では，固定染色したときに，原則としてラセンつくりがつられるが，と きイラセンは圓板狀體に連絡したり(ヒルムシロ屬の 1 種), まを粒狀體がラセンの糸によつて結ばれた形 (ハマュウ) となつているととるある。生體でも綠ラセンのみえることが多い。また，デンドロビウムのよ 5下同化產物が大部分で，綠ラセンはきわめて少なく，したがつて，粒狀にみえることもある。

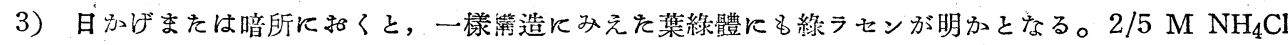
水溶液によって, コンテリクラマゴケの葉綠體などは，綠ラセンはふくらんで, ラセンづくりは不明瞭と なる。ある植物では, 一樣にみえる葉綠體も酸, アルカリ，固定液などによつて，綠ラセンを示す。綠ラ センを示す葉綠體は，日かげまをは暗所に 12 時間くらい拒くと，綠ラセンはさらに明膫となる。

4) 盛に原形質流動をしている細胞中で，葉線體は綠ラセンの明瞭な狀態と不明瞭な狀態との間に， らつり變わりをする場合もある。

5）色素體の基礎構造は綠ラセンであるが，grana または一樣棰造との間に天然にる，また人篇的に

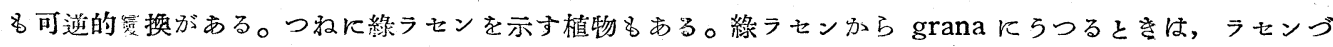
くりのみのこして, 葉綠素が grana にあたる部分にあつまつて grana を構成し, grana が綠ラセンに5 つるときには，葉綠素がラセンづくり全體にふくまれるよらとなるるのと思われる。

いろいろな植物の色素體の構造をつを゙の5に示すことができる。〔1]つねと綠ラセンを示するの (イワヒバ, オモト, サンショウモ, その他多くのシダ植物)。てれらの状態は, 人篇的に一樣構造に 變わることができる。〔2〕自然狀態で, 一樣構浩と綠ラセンとの間に轉換するもの（シャジクモ， フラスモ,ッノゴケその他)。これらの變換は人篇的にも行わせるととができる。〔3] Grana が細い 糸で,つづけられているるの（ヒルムシロ屬, ハマュウなど)。完全に grana の狀態になつている場 合もある。また，grana から綠ラセンにらつり變わる途中の狀態にも，てのよらすのみられることが ある(たとえばマッモ)。[4] Grana 狀と綠ラセン狀との間に，變換しらるもの（スギナ，イヌワ ラビ, ジャゴケ，タマネギ，マッョイグサ)。

6) 色素體の綠ラセンや基質のと, 膨潤, 失潤, 色素體の可逆的凝固などによって, 綠ラセンの變換 は說明できる。

7) Heitz (1936, 1936) の grana は, 綠ラセンの光學的隧面, 綠ラセン自身のふくらみ, ちみつに まいた部分，同化產物である場合のほかに，實際 grana を示して，綠ラセンとの間に變換する場合るする と考えられる。從來, あみ狀, せんい狀, 一樣, 䊀狀などと考えられた場合, 電子顯微鏡による像など ๖, 綠ラセンを元とのて珫明することができる。

8）葉綠體の外圍には，形態學的にはみにくいが，內部と構造のちがう膜部分があると考え得る。

9) コンテックラマゴ, ケタチクラマゴケ，イワヒバなどでは白色體, 有色體, 葉綠體は, 部分によ つてふつら型, 二割型, 和よび縱割型の三つの型の分裂を行ら。

10）分裂に要する時間は，ふつら型は本均約 14 時間，二割型は本均約 12 時間，綻割型は 60 分くら いである。色素體分裂と澱粉粓形成との間には，密接な關你がある。ふつら型の分裂は，夜は 19〜翌日 2 時に終るるのが多いが, 書間も澱粉形成と關係しつつ分裂が扣てなわれて和り，ほとんぞつね分裂期に あるるのがみられる。

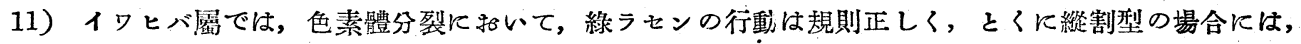


そのよらすが明かである。しかし，他の植物では，てのよらな規則正しさは失われている。

12）色素體分裂飞扣ける綠ラセンの行動は, 染色體のラセン糸の行動と似て和り, 前老はとれによっ て色素體の基本構造が 2 艮色素體に等しくわけられるしくみであり, 後者は遺倹子が 2 艮核に等しく分配

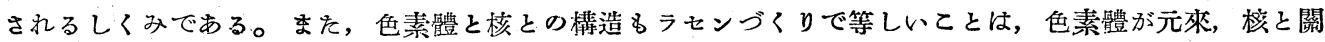
係が深いるのではないかといらことを思わせる。

13）いろいるな武藥の中に, イワヒバ屬の葉を入れて色素體分裂を行わせてみると, 分裂がやや早く なるもの, 阻害されるものなどがあり, 適當な方法によつて, 分裂促進の可能性があると考えられる。

14) ヤヌス綠 B で生體染色される細胞質中の小體をコンドリォン゙ームとして, ウラボシ科植物の生活 史についてしらべてみると、コンドリオン゙ームと色素體とはつねと別々に存在しているてとがわかる。精 子が受精までに, コンドリオン゙ームと色素體とを失い, 受精卵から發育してくる新しい植物では。色素體 やコンドリオゾームは，卵細胞かららけつぐてととなる。

15）イワヒバ屬では卵細胞は 1 色素體をもち，精子は色素體をともなおないから，受精卵は 1 色素體 で, 分裂組織はつねと 1 色素體である。組織の榡成部分のきめられた細胞は, 細胞分裂を停止し, 色素體 は分裂して，そのはたらきに應じて 2 色素體または多色素體の細跑となる。

16）葉の內部組織の細胞は, つねと大形 2 色素體をもつているが, 他の細胞でも分裂直後のある期間 は，つねに等しい數の色素體をるつている。このよらな色素體分配に扣ける規則性は, 核の支配より，む しろ細胞質の影響下にあるるのと思われ，細胞質中の， plasmagene とよぶべをるのの支配が考えられる。

17）色素體の行動に對して，ぞの程度に核が影響しているかは，將來の研究にまってととする。

本論文の發表に際して, 種々御配虑を給われる東大呚授理學博士篠遠喜人先生に媣く感謝の意を表す る。な和, ここに綜說した研究の一部は文部省科學研究費和よび額田坐物醫學研究所研究費によるもので あり,ここに御禮申电上げる。

\section{參 考 文 獻}

Alvarado, S. 1923. Ber. Deut. Bot. Ges. 41: 85 96: Anderson, E. G. 1935. Genetics 20: 70 83: Ardenne, M. von 1940. Naturwiss. 28: 113 127: Bowen, R. 1927. Biol. Bull. 56: 179 196: and Buck, L. H. 1930. Ann. of Bot. 44: 565 586: Bredow, H. 1889. Jahrb. wiss. Bot. 22: 349 414: Carter, N. 1919. Ann. Bot. 33: 215 454: - 1920. ib. 34: 265 285, 303 320: Cavers, F. 1914. New. Phyt. 13: 96 106: Cholodony, N. 1923. Ber. Deut. Bot. Ges. 41: 70 79: Cowdry, E. V. 1926. Amer. Nat. 60: 157 165: Cunha, A. G. de 1929. Arch. Portug. Sic. Biol. 2: $247 \sim 285$. 1944. Brotéria Ciěnc. Nat. 13: 49 72: Dangeard, P. A. 1919. C. R. Ac. Sci. Paris 169: 1005 1010: — 1920. ib. 170: 301 306, 709 714: Dangeard, P. A. 1931. Le Botaniste 12: 325 389: Doutrelinge, J. 1935. Boc. Kon. Akad. Weten. Amsterdam 38: 886 896: Emberger, I. 1920. C. R. Acad. Sci. Paris. 171: — 1921. Arch. Morph. gén. et exp., Fasc. 1: — 1927. Rev. gén. Bot. 39: 341 363: Forenbacher, A. 1911. Ber. Deut. Bot. Ges. 29: 648 660 : Friedrichs, G. 1922. Jahrb. wias. Bot. 61: 430 458: Frommann, C. 1880. Beobachtungens über Struktur und Bewegungserscheinungen des Protoplasmas der Pflanze. Jena: Fry-Wyssling, A. 1938. Submikroskopische Morphologie des Protoplasmas und Seiner Derivate (Protoplasma-Monogra phien Bd. 15) Berlin: Gicklhorn, L. 1932. Protoplasma 15: 71 89: Gicklhorn, L. 1932. b. 16: 571 592: Granicke, S. and Porter, K. R. 1948. (Rabinowitch, E. I. 1948. Sci. Amer. (8) Кょる): Guilliermond, A., Mangenot, G. et Plantefol, L. 1933. Traite de Cytologie végetale. Paris: Haberlandt, G. 1888. Flora 71: 291 307: Harper, R. H. 1919. Amer. Jour. Bot. 6: 273 300: Heitz, E. 1922. Untersuchungen über die Teilung der Chloroplasten usw. Strasburg: — 1925. Zeit. f. Zellf. 2 : 
29 86: — 1936. Planta $26: 134 \sim 163:$

1936. Ber. Deut. Bot. Ges. 54 : 362 368: 今井喜 孝 1936. Zeits. ind. Abst. Vererbl. 71: 61 83: Kausche, G. A. und Ruska, H. 1940. Naturwiss. 28: 303: Kirby, K. S. N. 1928. Jour. Roy. Micr. Soc. 48: 10 35: 清原 金 1926. Bot. Mag. (Tokyo) 40: 1 6: Krupko, S. 1926. Acta Soc. Bot. Poloniae 4: 77〜86: 楠 正貫・川崎義雄 1936. Cytologia 7: 530 534: Küster, E. 1935. Die Pflanzenzelle. Jena: Lewitzky, G. A. 1910. Ber. Deut. Bot. Ges. 28: 538 546: — 1925. Arch. wiss. Bot. 1: 310 316: Liebaldt, E. 1913. Zeit. Bot. 5: 65 112: Lloyd, D. E. 192j. Michigan Ac. Sc. Arts and Lett: Loui, J. von 1981. Planta 12: 191 238: Löwschen, A. M. 1914. Ber. Deut. Bot. Ges. 31: 266 270: Lundegårdh, H. 1910. Jahrb. wiss. Bot. 48: 285 378: Mangenot, G. 1925. C. R. Ac. Sci. $180: 157 \sim 160$ : Menke, W. 1940. Naturwiss. 28 : 158 159: — und Koydl, E. 1939. Naturwiss. $27: 29:$ Ma, R. M. 1928. Amer. Jour. Bot. 15: 277〜 284: Metzner, P. 1922. Ber. Deut. Bot. Ges. 40: 125 129: Meyer, A. 1883. Das. Chlorophyllkon in chemischer, morphologischer und biologischer Beziehung. Leipzig : - 1911. Ber. Deut. Bot. Ges. 29: 158 160: Moreau, M. F. 1914: Bull. Soc. Bot. France 61: 70 74: Mohl, H. von 1855. Bot. Zeit 13: 89 99, 105 115: Motte, J. 1928. Ann. Sci. Nat. Bot. 20: 293 543: Mottier, D. M. 1918. Ann. Bot. 32 : 91 114: — 1921. ib. 35: 349 364: Muller, H. J. 1947. Proc. Roy. Soc. B, 134: 1 37: Nägeli, C. von 1858: Die Stärkekörner. Zürich: — 1866. Sitzb. K. Akad. Wiss München 2: 280 312: Neměc, B. 1910. Das Problen der Befruchtungsvorgänge und andere zytologische Frage. Berlin: Newcomer, E. H. 1946. Amer. Jour. Bot. 33 : 221, 684 697: Noack, K. L: 1921. Zeit. Bot. 13: 1 35: Pringsheim, N. 1881. Jahrb. wiss. Bot. 12: 288 437: — 1882. ib 13: 377 , 490: Randolph, F. 1922. Bot. Gaz. 73: 337 375: Reinhard, H. 1933. Frotopalsma 19: 541 564: Sachs, J. 1862. Bot. Zeit. $20: 365 \sim 373:-1863$. Flora $46: 195 \sim 204,214 \sim 220: 1864$ : Bot. Zeit. 22: 289 294: 坂村 徹 1933. Jour. Fac. Sci. Hokkaido Imp. Univ. Ser. V, Vol. II, No. 4: 287〜316: 1933. 植物生理學. 東京：Sapehin, A. H. 1915. Arch. Zellf. 13: 319 398： Scarth, G. W. 1924: Quart. Jour. Exp. Physiol. 14: 99 122: Scherrer, A. 1914. Flora 107: 1 56: Schimper, A. F. W. 1883. Bot. Zeit. 41: 105 111, 121 131, 137 146, 153 162: — 1885. Jahrb. wiss. Bot. 16: 1 247: Schmitz, F. 1882. Verh. Naturhist. Ver. Preuss. Rheinl. u. Westf. 41: Schürhoff, P. N. 1924. Die Plastiden. Jena: Senjaninova, M. 1927. Zeit. Zellf. Mikr. Anat. 6: 464 492: _ 1927. ib. 6 : 493 508: Senn, G. 1907. Arch. Sci. Phys. Nat. 24 : 499 501: Sharp, L. W. 1934. Introduction to Cytology. New. York and London: 新家浪雄 1939. Mem. Coll. Sci. Kyoto Imp. Univ. Ser. B. $15:$ 1 126: Sorokin, H. 1938. Amer. Jour. Bot. 25: 28 33: Stone, W. E. 1932. Jour Agr. Res. 45: 421 435: Strasburger, E. 1880. Ueber Zellbildung. und Zellteilung. Jena : Strohmeyer, G. 1935: Planta 24: 47:0 509: Tschirch, A. 1883. Ber. Deut. Bot. Ges. 17: 202 207: 植田利 器造 1949. Bot. Mag. [Tokyo] 62: 62 63: — 1949. 生物學の進步第 4集. 4 242 259: Wager, H. 1905: Rep. Brit. Assn. Adv. Sci. 75: 573 575: Weier, E. 1936. Amer. Jour. Bot. 23: 645 652: Weier, 1938. Protoplasma 31: 345 350: 山內集雄 1908. Bot.' Gaz. 45: 1 30：湯淺 明 1939. Jap. Jour. Gen. 15: 47〜61: — 1940. Jap. Jour. Bot. 10:465 475: — 1940. Bot. Mag. (Tokyo) 54: 196 197. — 1940. ib. $54: 215 \sim 222:-1940$. ib. $54: 338 \sim 342:-$ 1944. ib. 58:53〜 61: - 1947: Seibutu 2: 129 135: — 1947. Bot. Mag. (Tokyo) 60: 703 714: — 1949. ib. 62: 727〜 728: 一一上方澄子 1945. Kagwaku 15:21 22: 一一山崎典子 1946. ib. 16: 12 14: Zirkle, C. 1926. Amer. Jour. Bot. $13: 301 \sim 320:-1926$. ib. $13: 321 \sim 341$. 